УДК 351.778.511(497.11); 711.58(=214.58)(497.11)

CERIF: S111, S112

\author{
Marko Davinić, $\mathrm{PhD}^{*}$
}

\title{
THE LEGALIZATION OF INFORMAL ROMA SETTLEMENTS IN THE REPUBLIC OF SERBIA - A NECESSARY STEP PRIOR TO LEGITIMATION -
}

There have been several attempts of the Government of the Republic of Serbia to legalize structures that have been constructed contrary to its building and land use laws. In spite of all expectations, the results achieved have been insignificant. In order to legalize the highest number of illegally constructed structures and to undertake preventive action against the emergence of new illegal construction, the new Law on the Legitimation of Buildings was adopted in November, 2015. However, the author argues that this act, despite its newly simplified and inexpensive procedure, will not enable the legalization of buildings within informal Roma settlements due to the substandard nature of these settlements (most of which are built on land in public ownership or on land that is of an unregulated or unclear legal status). Therefore, the author advocates a need for the enactment of special Law on the Legalization of Sustainable Informal Roma Settlements as a necessary prerequisite for the subsequent legitimation of individual structures within such settlements.

Key words: Informal Roma Settlements. - Legalization. - Legitimation. - Sustainability - Affirmative Action.

\section{INTRODUCTION}

Over the last few decades, illegal building in Serbia has been tolerated as a manner of "informal social policy". The reasons for this phenomenon lie in the inability of the state to provide decent housing for all its citizens, which has also born the threat of social unrest. ${ }^{1}$ All previous bg.ac.rs

* Associate Professor at the University of Belgrade Faculty of Law, markod@ius.

1 See: Platforma za predlaganje Lex specialisa o legalizaciji romskih naselja, Standing conference of the Roma associations of the citizens - The league of Roma, 2 . 
attempts of the Government of the Republic of Serbia to legalize illegal buildings have resulted in utter failure, with a negligible number of Roma having solved their housing problems through the legalization process.

The problem of informal Roma settlements is the result of historical and socio-economic circumstances in the former Yugoslavia, in addition to wars and subsequent migration events which occurred in the last twenty-five years. Namely, under the former Socialist regime, an insignificant percentage of employed Roma were included in the allocation of socially-owned flats, while the majority were forced to find housing solutions, by their own means, outside the system. ${ }^{2}$ Informal Roma settlements, therefore, represent a spatial manifestation of social inequality, which is of a complex and multidimensional nature, and requires a range of social support measures. ${ }^{3}$ Moreover, although envisaged by the Constitution of the Republic of Serbia, affirmative measures are not being elaborated on and implemented sufficiently, neither by Serbian laws nor bylaws.

Unfortunately, such an approach has not changed with the Law on the Legitimation of Buildings adopted in November 2015. The main objective of this paper is to delineate the inadequacy and insufficiency of the existing legal framework and the necessity of passing the Law on the Legalization of Sustainable Informal Roma Settlements as a prerequisite for the subsequent legitimation of individual structures within such settlements. This approach would also represent a positive model for dealing with the issue of informal Roma settlements in other countries, given that there is virtually no European state in which this minority is not present.

\section{ATTEMPTS TO LEGALIZE ILLEGALLY CONSTRUCTED BUILDINGS IN THE REPUBLIC OF SERBIA}

Over the previous two decades, there have been several attempts of the Government and National Assembly of the Republic of Serbia to legalize structures that have been constructed contrary to the law. ${ }^{4}$ Each subsequent piece of legislation has been more liberal in comparison to

2 Ibid.

3 Self-made Cities, In Search of Sustainable Solutions for Informal Settlements in the United Nations Economic Commission for Europe Region, United Nations, New York - Geneva 2009, 92-93.

4 The Law on Special Conditions for the Issuance of Construction and Use Permit for Designated Objects, Official Gazette of the RS, No. 16/97; The Law on Planning and Construction, Official Gazette of the RS, No. 47/2003, 34/2006; The Law on Planning and Construction, Official Gazette of the RS, No. 72/2009, 81/2009, 64/2010, 24/2011, 121/2012, 42/2013, 50/2013, 98/2013, 132/2014, 145/2014, The Law on Special Conditions for Registration of Right of Ownership on Facilities Constructed 
that previous. In spite of all expectations, the results achieved by them have been insignificant. The percentage of legalized structures has been negligible in comparison to the number of submitted requests; ${ }^{5}$ moreover, the number of applications has not even been close to what should be otherwise expected. ${ }^{6}$ It is a devastating fact that the number facilities illegally constructed has not decreased, but has only risen over the years. Illegal builders have not been motivated to initiate legalization procedures, owing to the fact the process is considered to be complicated and expensive, as well as that illegal builders rarely face legal consequences. They have found "safety in numbers", since the number of illegal buildings in Serbia is estimated to be at one and a half million. ${ }^{7}$

Frequent changes in laws without yielding significant results have led only to the fall of the authority of the State and its agencies, while the legalization process has come to be perceived as a form of amnesty. ${ }^{8}$ Attributed to the failure and ineffectiveness of previous laws, not merely in Serbia but in the region as a whole, are the following: insufficient administrative capacities, complicated procedures, political pressure, legal solutions that stimulate further illegal building (lowering criteria, extension of deadlines, the legalization procedure cheaper than lawful building), and ongoing tolerance to the phenomenon. ${ }^{9}$

The Law on the Legalization of Objects of 2013 followed as a consequence of the decision of the Constitutional Court of the Republic of Serbia on the incompatibility of certain provisions of the Law on planning and construction of 2009 with the Constitution. ${ }^{10}$ The Constitutional

Without a Building Permit, Official Gazette of the RS, No. 25/2013, 145/2014, The Law on Legalization of Objects Official Gazette of the RS, No. 95/2013, 117/2014.

5 See: Milanka Belić, „Legalizacija bespravno sagrađenih objekata“, Bilten republičkog javnog pravobranilaštva 1/2014, 63.

6 According to the latest report, approximately 771,000 applications for legalization have been submitted, compared to one and a half million illegally constructed buildings. See: Explanation of the draft Law on the Legitimation of Buildings: http://www.mgsi.gov. rs/lat/dokumenti/nacrt-zakon-o-ozakonjenju-objekata, last visited 10 October 2015.

7 According to the Republic Geodetic Authority, there are 4,671,899 structures in Serbia, of which 1,996,479 buildings serve for family housing, and 36,321 for collective housing. The number of registered illegal buildings is estimated to be 1,476,433. Ibid.

8 See: Đorđe Mojović, Miodrag Ferenček, Izazovi regularizacije neformalnih naselja u jugoistočnoj Evropi, Pregled relevantnih zakona i prakse iz oblasti urbanističkog planiranja i legalizacije, NALAS (Network of Associations of Local Authorities of SouthEast Europe), Skoplje, 2011, 99, 129.

9 See: Ibid., 105-106.

10 The provisions of Article 185-200 of the Law on planning and construction (Official Gazette of the RS, No. 72/2009, 81/2009, 64/2010, 24/2011) were declared unconstitutional by the Court decision no. IUz $-295 / 2009$ of $6^{\text {th }}$ December 2012. Six months after the ruling, on June $7^{\text {th }}, 2013$, the here-mentioned provisions ceased to be in force as a result of the publication of the Court's decision in the Official Gazette. See: http://www.ustavni.sud. 
Court found in its decision that privileged conditions for the subsequent obtaining of a building permit had given unfounded privileges to persons who had violated building regulations. ${ }^{11}$ According to the Court, these provisions violated the principle of the rule of law, legal certainty, and equal application of the law (non-discrimination). ${ }^{12}$ In other words, the Constitutional Court found that legalization is only allowable when it is based on the subsequent performance of all legal obligations that were required for lawful builders.

To elucidate, with this decision, the Constitutional Court did not declare the legalization per se unconstitutional, but the manner in which it had been conceived and regulated. Furthermore, in permitting the legalization of structures that had been illegally erected during the validity of the Law on Planning and Construction of 2003, the disputed Law of 2009 also implicitly approved the inaction of authorities. Namely, it "legalized" the fact that illegal construction was not prevented or remedied by public authorities in practice. Instead of implementing a statutory sanction in the form of a facility's removal, the law suspended the said sanction and tacitly replaced it with the right to legalization. ${ }^{13}$

It is important to underscore that the Constitutional Court found that the privileged position in the process of legalization can be allowed only if it relates to a group of persons whose social situation demands the positive measures (affirmative action) envisaged by the Constitution. ${ }^{14}$

The Law on the Legalization of Objects enacted in 2013 has not led to the desired outcomes it envisioned and the number of illegal build-

rs/page/view/sr-Latn-CS/80-101744/saopstenje-sa-28-sednice-ustavnog-suda-odrzane-6decembra-2012-godine-kojom-je-predsedavao-dr-dragisa-slijepcevic-predsednik-ustavnogsuda; http://www.bdklegal.com/upload/documents/newsletter/2013/BDK\%20Newsletter\%20 10.pdf, last visited 24 August 2015.

11 Constitutional Court Decision no. IUz $-295 / 2009$ of $6^{\text {th }}$ December 2012: http://profisistem.com/zakoni/strana/916, last visited 29 September 2015; Dimitrije Lukić, President of the Sokobanja municipality, cited the case in point of two neighbors who were building similar houses at the same time. One had acted in accordance with regulations and built his house with permission, the other without a single piece of documentation. The law abiding citizen needed to pay 22,000 Deutsch Marks in land compensation, while his fraudulent neighbor paid nothing and erected his house much sooner. See: http://www. politika.rs/rubrike/Ekonomija/Legalizacija-sesti-put-za-deset-godina.lt.html, last visited 30 September 2015.

12 Constitutional Court Decision no. IUz $-295 / 2009$ of December $6^{\text {th }}, 2012$ : http://profisistem.com/zakoni/strana/916, last visited 29 September 2015.

13 Ibid.

14 Ibid; See: Article 21 (4) and Article 76 (3) of the Constitution of the Republic of Serbia, Official Gazette of RS, No. 98/2006; „The court admitted that it may be constitutional to apply different legal regimes to the same right if this were necessary in order to level the playing field for persons or groups whose social status justifies affirmative action." See: http://www.bdklegal.com/upload/documents/newsletter/2013/ BDK\%20Newsletter\%2010.pdf, last visited 29 September 2015. 
ings has not seen a significant drop. Consequentially, a new Law on the Legitimation of Buildings was adopted in November, 2015. The principal objective of the new Law is to legitimize the highest number of illegally constructed objects and to convert them into the procedural flow, as well as to undertake preventive action against the emergence of new illegal construction. ${ }^{15}$ According to the Minister of Construction, Transport and Infrastructure, "legalization will be inexpensive, simple, and fast. This law is different from all those previous in that it is not left to the will of citizens or legal persons to legalize their structures or not, but the state. The government renders a decision on demolition of those who did not submit a single document". ${ }^{16}$ However, these benefits could bear negative consequences on municipal budgets, since illegal constructors will be exempted from paying fees for construction land, which is one the largest sources of revenue for local governments. ${ }^{17}$

The draft stipulates that a list of all illegally constructed buildings will be made and utilized by building inspectors. After registration of the structure for which there has been no request for legalization, a building inspector is obliged to issue a decision on the demolition of the building. It is delivered to the owner of the illegally constructed facility and the competent authority for the legitimization of buildings as to initiate ex officio procedure for the structure's legitimization. Thus, the state, treating this issue as a matter of public interest, will self-start and guide the process of legitimization. It will no longer be upon the will of the owners of illegally constructed buildings as to whether they will file a request or not. Nevertheless, this law does not carry out the legalization of buildings itself, meaning the subsequent collection of all documents required for the construction of a new facility. With this law, the Republic of Serbia will conduct the legitimization of buildings in the public interest, under prescribed minimum geodetic-technical stipulations and other necessary documentation. ${ }^{18}$

It must be stressed that both legalization and legitimation are to be carried out in the public interest, but only in the latter is it made explicit in the provisions of the law. ${ }^{19}$ Furthermore, the governmental body in charge initiates the procedure of legitimation ex officio, ${ }^{20}$ which demon-

15 See: Explanation of the draft Law on the Legitimation of Buildings: http://www. mgsi.gov.rs/lat/dokumenti/nacrt-zakon-o-ozakonjenju-objekata, last visited 15 October 2015.

16 http://www.politika.rs/rubrike/Ekonomija/Pocinje-legalizacija-po-novimpravilima.lt.html, last visited 25 October 2015.

17 Ibid.

18 See: Explanation of the draft Law on the Legitimation of Buildings: $h t t p: / / w w w$. mgsi.gov.rs/lat/dokumenti/nacrt-zakon-o-ozakonjenju-objekata, 15 October 2015.

19 Art. 2 of the Law on the Legitimation of Buildings.

20 Art. 7 (9) of the Law on the Legitimation of Buildings. 
strates the direct engagement of public interest. However, one can set a reasonable question as to whether the process of legitimation (regardless of the predominance of public interest) undermines the principle of equality and non-discrimination, which was the main reason for the adoption of the aforementioned decision of the Constitutional Court on the unconstitutionality of the provisions of the Law on Planning and Construction. This is especially important if one bears in mind the position of the Court that, "the establishment of such types of privileges cannot be justified by the public/general interest to conduct legalization as a legitimate aim". ${ }^{21}$ Of course, it remains to be seen what will be the possible position of the Constitutional Court to the new law.

\section{HOUSING CONDITIONS OF ROMA IN THE REPUBLIC OF SERBIA}

The Roma community has been residing in Serbia for centuries and is widely recognized as the most endangered national minority, ${ }^{22}$ despite the protection guaranteed in numerous international and domestic acts. ${ }^{23}$

21 Constitutional Court decision no. IUz - 295/2009 of $6^{\text {th }}$ December 2012: http:// profisistem.com/zakoni/strana/916, last visited 15 October 2015.

22 See: Foreword of the Strategy for Improvement of the Status of Roma in the Republic of Serbia, Belgrade, 2010, 5; It is important to emphasize, that the Roma population in Serbia is not homogeneous, as can be assumed; three main groups of Roma exist in Serbia: Arli/Erli in the South, and Gurbet and Kalderash in the North. The distinction is based primarily on the languages spoken by these groups. See: Ethnic Minorities in Serbia, An Overview, OSCE, February 2008, 19: http://www.osce.org/ serbia/30908?download=true, last visited 20 October 2015; Furthermore, the Roma population has other mitigating factors of diversity: „There are long established residents, refugees or internally displaced persons (IDPs) from recent conflicts, returnees from Western countries, seasonal workers (...), and a very small number of travelers. What all these groups have in common is extreme deprivation in economic and social terms, and daily lives marked by discrimination". Vladimir Macura, Zlata Vuksanović, Roma Housing and Settlements in South-East Europe, Profile and Achievements in Serbia in a Comparative Framework, Summary and Recommendations, OSCE, ODIHR, Warsaw 2006, viii.

23 Numerous legal and strategic documents have been adopted in the Republic of Serbia with the aim of improving the situation of Roma communities. Among the laws of special importance are the Law on Protection of the Rights and Freedoms of National Minorities (2002), Anti-Discrimination Law (2009), and the Law on Social Housing (2009), while the main strategic documents have been the Poverty Reduction Strategy (2003), the Strategy for the Improvement of status of Roma (2009), and the Strategy for the Prevention and Protection against Discrimination (2013). The Republic of Serbia has ratified a number of international treaties adopted under the auspices of the United Nations which, inter alia, prohibits discrimination and guarantees the right to housing: the International Covenant on Civil and Political Rights, the International Covenant on Economic, Social and Cultural Rights, the Convention on the Elimination of All Forms of Racial Discrimination, the Convention on the Elimination of All Forms of Discrimination 
Furthermore, the exact number of Roma in Serbia is difficult to determine and a lack of reliable data negatively impacts their housing situation. ${ }^{24}$ According to the 2011 census, there were 147,604 Roma recorded, representing $2.05 \%$ of total population. ${ }^{25}$ There is a general consensus, however, that the number of Roma is several times higher and its estimates range from 250,000 to 400,000 individuals. ${ }^{26}$ Some Roma NGOs claim

against Women, the Convention on the Rights of the Child, the Convention against Torture and Other Cruel, Inhuman or Degrading treatment or Punishment, the Convention on the Rights of Persons with disabilities and the Convention on the Protection of All Persons from enforced Disappearances. Furthermore, the Republic of Serbia has ratified a number of international conventions adopted within the Council of Europe, such as the European Convention on Human and Minority Rights and the revised European Social Charter as well as the Framework Convention for the Protection of National Minorities. Within the EU, several directives prohibiting discrimination have been issued. Of particular importance is Directive 2000/43 which prohibits discrimination on the basis of race or ethnicity. In addition, Serbia is a signatory of the Vienna Declaration on National and Regional Policy and Programmes regarding Informal Settlements in South Eastern Europe as of September $28^{\text {th }}, 2004$. Finally, the Declaration of the Decade of Roma Inclusion 2005-2015 was signed in Sofia on February $2^{\text {nd }}, 2005$, by the prime ministers of Central and Southeast European participant countries, whose main objective has been to provide a basis for the improvement of living conditions among the Roma and for a reduction in the differences between them and the non-Roma majority. While the situation of the Roma in Serbia has been generally advanced with the enactment of these legal and strategic documents, the right to adequate housing still remains elusive for the vast majority of them. As civil society organizations have observed, ,although we can affirm that Roma interests are considerably incorporated into different national strategic documents, the general problems characteristic to all these documents are the unrealistic goals, insufficient - if any - budgetary allocations, excessive reliance on foreign donations, and a lack of effective monitoring and evaluation mechanism“. Osman Balić, Đurđica Ergić, Stevan Nikolić, Đokica Jovanović, Slavica Vasić, Civil Society Monitoring on the Implementation of the National Roma Integration Strategy and Decade Action Plan in Serbia in 2012 and 2013, Decade of Roma Inclusion Secretariat Foundation, Budapest 2014, 8; The Strategy for Improvement of the Status of Roma in the Republic of Serbia, 9; Marko Davinić, Vladimir Macura, Miodrag Ferenček, Žarko Klisarević, Osman Balić, The Draft Law on the Legalization of Sustainable Roma Settlements, Standing Conference of the Roma Associations of the Citizens - The League of Roma, Belgrade 2014, 12-13.

24 See: Best Practices for Roma Integration, Regional Report on Housing Legalization, Settlement Upgrading and Social Housing for Roma in the Western Balkans, OSCE/ODIHR, Warsaw, 2013, 39: http://www.osce.org/odihr/115737?download=true, last visited 2 November 2015.

252011 Census of Population, Households and Dwellings in the Republic of Serbia, Ethnicity, Data by municipalities and cities, Statistical Office of the Republic of Serbia, Belgrade 2012, 14-15: http://pod2.stat.gov.rs/ObjavljenePublikacije/Popis2011/ Nacionalna\%20pripadnost-Ethnicity.pdf, last visited 21 October 2015; See also: the cartographic presentation of the share of Roma people in the total population of municipalities and cities in the Republic of Serbia: Ibid., 95.

26 Ethnic Minorities in Serbia, 19-20; The most relevant and comprehensive study was conducted in 2002 under the title „Romany Settlements, Living Conditions and Possibilities of Integration of the Roma in Serbia: in order to Take Effective Measures as to Improve Living Conditions and Examine the Possibilities of Integration“. The research 
that there are more than 750,000 Roma in Serbia, but such assessments may be exaggerated. The current expectation is that this number is on the rise as Roma are repatriated from Western Europe to Serbia based on readmission agreements. ${ }^{27}$

The majority of the Roma population in Serbia have been living in informal settlements, in extreme poverty, and are under constant threat of forced eviction. They have no registered permanent residence and personal documents, are unfamiliar with their rights, and are subject to different forms of discrimination and stigmatization. ${ }^{28}$ Therefore, it is recognized that "a residence with secure living conditions is a prerequisite to the recognition and fulfillment of other rights". ${ }^{29}$

In Serbia, Roma settlements often represent traditional parts of the towns and cities in which they are located. In addition to the living conditions being very poor and their area as quite small, they are also overpopulated. Their poverty is the result of the social exclusion, prejudices, and intolerance that Roma have experienced in most European countries for centuries. ${ }^{30}$ Contrary to prejudices, the majority of the Roma do not want

team comprised representatives of the academic community under the direction of Božidar Jakšić, from the Institute for Philosophy and Social Theory. This study estimated the number of Roma in Serbia to be approximately 250,000. In 593 settlements with more than 100 inhabitants or more than 15 families, there was a total of 210,353 Romany natives and 46,238 Romani displaced from Kosovo. This methodological approach meant that the objective of the investigation was not to determine the exact number of the Roma population, rather an approximate one. As a consequence, the authors of this investigation assume that the real number of Roma inhabitants is roughly $30 \%$ higher. See: Goran Bašić, „Settlements and Population Density of the Romanies in Serbia“, Umetnost preživljavanja, Gde i kako žive Romi u Srbiji (ur. B. Jakšić, G. Bašić), Institut za filozofiju i društvenu teoriju, Beograd 2005, 200-201; When discussing the number of Roma, one should be cautious due to the phenomenon of 'ethnic mimicry' or 'ethnic exodus'. These terms are used to describe Roma families who have managed to break away from poverty and then cease to identify themselves as Roma, due to pejorative attitudes, prejudices and stereotypes towards this ethnic group. See: Ibid., 201; Božidar Jakšić, „Uslovi života romske porodice u Srbiji“, Umetnost preživljavanja, Gde i kako žive Romi u Srbiji (ur. B. Jakšić, G. Bašić), Institut za filozofiju i društvenu teoriju, Beograd 2005a, 87.

27 Ethnic Minorities in Serbia, 20.

28 See: Ivanka Kostić, „Romi u Srbiji - glavni problemi i prepreke u pristupu pravima (The Roma in Serbia - The Main Problems and Obstacles in Accessing Rights)“, Prilozi Strategiji unapredjenja položaja Roma (ur. T. Varadi, D. Djordjević, G. Bašić), Zaštitnik građana, Beograd 2014, 98; On different forms of discrimination of the Roma population, see: Nevena Petrušić, „Tipologija slučajeva diskriminacije Roma u pravnoj praksi poverenika za zaštitu ravnopravnosti (Classification of cases of Discrimination Against Roma in the Legal Practice of Comissioner for Protection of Equality)", Prilozi Strategiji unapredjenja položaja Roma (ur. T. Varadi, D. Djordjević, G. Bašić), Zaštitnik građana, Beograd 2014, 73-91.

29 V. Macura, Z. Vuksanović, vii.

30 See: Zlata Vuksanović-Macura, „The Mapping and Enumeration of Informal Roma settlements in Serbia“, Environment \& Urbanization 2/2012, 685. 
to live in ethnically homogenous environments. However, they often feel that they have no alternative due to their social status and inadequate incomes. ${ }^{31}$

As Bašić has observed, structural poverty is clearly evident in many such settlements and is deeply connected to political, legal, social, economic, ethnic and religious issues. ${ }^{32}$ In order to describe their position in society, Miloš Macura characterizes the Roma as being "poorer than the poorest". ${ }^{33}$ Their position is such that many experts distinguish them as a separate ethnic class altogether. ${ }^{34}$ However, this does not mean that all Roma settlements are in poor and irreparable condition.

31 When asked, „Do you agree with the statement: Roma are better off living in their own settlements rather than next to citizens of other nationalities?", merely $11.9 \%$ totally agreed and $77.6 \%$ of respondents fully disagreed. This survey was carried out by associates of Serbia's Protector of Citizens on a sample of 500 respondents in 47 Roma settlements and in 30 municipalities. See: Izveštaj o sprovođenju Strategije za unapređenje položaja Roma sa preporukama, Zaštitnik građana, Beograd 2013, 1, 105-106: http://www. ombudsman.rs/attachments/3115_IZVESTAJ\%20ZG\%20O\%20SPROVODJENJU\%20 STRATEGIJE.pdf, last visited 1 November 2015; The same survey showed that Roma hold the place and country in which they live as important to them, despite their previous nomadic life. Ibid., 55.

32 G. Bašić (2005), 195; However, the aforementioned survey conducted in 2002 found that almost two thirds $(64.7 \%)$ of the interviewed Roma families said their housing conditions were fine, while just one third (33.0\%) replied that they were bad. Božidar Jakšić, „Living conditions of the Roma family in Serbia“, Umetnost preživljavanja, Gde $i$ kako žive Romi u Srbiji (ur. B. Jakšić, G. Bašić), Institut za filozofiju i društvenu teoriju, Beograd 2005b, 230; This finding is an obvious indication of the discrepancy between the objective situation and subjective opinions, which is not an exclusive characteristic of the Roma population. Namely, the root of this phenomenon should be sought in the desire of people to present themselves and their living conditions better than they really are (,keeping up appearances“).

33 For citation, see: Goran Bašić, „Siromaštvo Roma i afirmativne mere (Roma Poverty and Affirmative Action)“, Prilozi Strategiji unapredjenja položaja Roma (ur. T. Varadi, D. Djordjević, G. Bašić), Zaštitnik građana, Beograd, 2014, 10; Bašić added that in the absence of a stronger national program and movement, poverty has become the guardian of autochthony of the group and identity. Such poverty differs from ordinary poverty by social exclusion of the Roma people. See: Ibid., 11-12; The difficult position of the Roma is also demonstrated by the fact that just one out of one hundred Roma reaches sixty years of age, as well as that the infant mortality rate of Roma children is 3.5 times higher than that of the majority community. Cited in: Prednacrt Zakona o legalizaciji održivih neformalnih naselja (Draft Law on the Legalization of Sustainable Informal Roma Settlements), Standing Conference of the Roma Associations of the Citizens - The League of Roma, Beograd 2014, 8; Nevertheless, Jakšić observed that „the overall economic, political, cultural and moral catastrophe in which Serbian society (...) found itself in the last decade of the $20^{\text {th }}$ century has certainly brought non-Roma closer to Roma, and vice versa. This, for the time being, means just equality in nothingness“. B. Jakšić, (2005b), 261.

34 Izveštaj o sprovođenju Strategije za unapređenje položaja Roma sa preporukama, 21. 
There are different criteria that should be taken into consideration when deciding what type of Roma settlement is able to be improved and legalized and what is not. The main criteria include the sustainability of the settlement and ownership status of the land, in addition to the age of the settlement, its position within the city (proximity to infrastructure and public transportation), environmental conditions, and other similar concerns. ${ }^{35}$

When taking into account these above listed criteria, four distinct types of Roma settlements in Serbia can be differentiated: slum, poor, conditionally functional, and functional. $A$ slum settlement is defined as being haphazardly built on land that belongs to owners who are not the inhabitants. A poor settlement is erected on land that belongs to the inhabitants' themselves, but the building quality of the structures is substandard and is in further decline due to poor maintenance. A conditional functional settlement is one in which the structures can meet standard building regulations, but are not built on land that belongs legally to the inhabitants. Finally, a functional settlement is one in which the structures meet standards and are built on land that belongs to the inhabitants themselves. Excluding slums, all other types of settlements, in general, can and should be legalized in respect to solutions needed for their respective issues. ${ }^{36}$

In a slightly differing view, Vuksanović-Macura categorizes Roma settlements in Serbia into three different types: slums, unserviced settlements, and ordered settlements. According to her, slums make up approximately 20 percent of all Roma settlements. They are developed on illegally occupied land at the outskirts of urban areas and are built by the most impoverished and vulnerable groups. Slums consist of overcrowded barracks without basic infrastructure and public spaces. These settlements cannot be improved and are supposedly to be removed when alternative accommodation to their inhabitants is provided. ${ }^{37}$

By far the largest, unserviced settlements make up 69 percent of all Roma settlements. They are built on land that belongs to a variety of owners (the state, municipalities, enterprises, and the Roma themselves). In general, these settlements are quite old, where the living units are constructed of solid materials. According to strategic documents of the Republic of Serbia, the majority of such settlements should be upgraded and legalized. ${ }^{38}$

35 Guidelines for the Improvement and Legalization of Informal Roma Settlements, 19.

36 Compare: Ibid., 19-20.

37 Z. Vuksanović-Macura, 689-690.

38 Ibid. 
Finally, ordered settlements make up 11 percent and consist of single-family houses built of solid materials and whose infrastructure is complete. Most of these structures have been erected legally by Roma who have been working abroad as guest workers. ${ }^{39}$ It is obvious, that settlements of this group do not need further legalization, but improvement in terms of social services and communal infrastructure.

In the Guidelines for the Improvement and Legalization of Informal Roma Settlements, it is stressed that "improvement and legalization of Roma settlements is a better strategy than any other. (...) Improvement is the cheapest socially most painless and most adequate method for the inhabitants". ${ }^{40}$ However, the statement that "all categories of Roma settlements - including the most impoverished, can and should be improved" does not actually take into account the reality and gravity of the situation. ${ }^{41}$ As has been already mentioned, slums are categorically unable to be improved nor legalized. However, it does not mean that all of them should be removed without developing feasible alternatives for their inhabitants.

\section{NEEDS FOR AFFIRMATIVE ACTIONS IN THE LEGALIZATION OF ROMA SETTLEMENTS}

One can reasonably pose the question as to why there is a need for a special law that would solely regulate the informal settlements of the Roma. Even some international organizations argue that the legalization of these settlements should not be regulated separately from the rest of the population. ${ }^{42}$

Nonetheless, Roma poverty is significantly different from the poverty of others, as the Roma are unable to overcome it without govern-

39 Vuksanović-Macura stresses that it is not easy to make a clear distinction between these settlements, especially the first two groups. Ibid.

40 Guidelines for the Improvement and Legalization of Informal Roma Settlements, 5-6; These Guidelines were adopted in 2007 by the Ministry for Capital Investments with the objective to help municipalities during this process. Nevertheless, only two (Prokuplje and Knjazevac) out of 148 municipalities in Serbia legalized Roma settlements according to these recommendations. See: O. Balić et al., 73.

41 Guidelines for the Improvement and Legalization of Informal Roma Settlements, 5.

42 See, for instance, the OSCE report: „Roma are not the only group requiring housing legalization and support. Programmes that aim to provide long-term special treatment for Roma populations in the areas of land and housing should be avoided, as they will eventually cause resentment among the general population, a large proportion of which suffers from similar constraints with regard to the complexities of legalization". Best Practices for Roma Integration, 7. 
ment assistance and social solidarity. Most of them find themselves in a vicious circle of poverty: "they are unemployed because they are poor and unskilled, and they are poor because they are unemployed or perform the lowest paid jobs". ${ }^{43}$ Such "structural' poverty is unique because of the social exclusion of the Roma population and its perseverance. ${ }^{44}$ Thus, affirmative measures should provide equitable access to rights for those citizens who, due to the long-term impact of unfavorable socio-economic factors, are in the position that is the source of their civic inequality and social exclusion. In other words, equality does not necessarily mean fairness for the disadvantaged. ${ }^{45}$

Affirmative measures represent an exception to the rule of prohibition of discrimination. ${ }^{46}$ In general terms, an affirmative measure "comprises all sort of measures aimed to help minorities or social disfavored groups to overcome decades of past societal discrimination", ${ }^{47}$ and can be defined as an attempt to make progress towards a substantive rather

43 B. Jakšić (2005b), 220.

44 G. Bašić (2014), 12; As Bašić suggests, ,they are a socially, economically, politically and in every other sense powerless social group that cannot ovecome the existing situation without the support of the broader social community and intervention of state administration“. G. Bašić (2005), 218; Stanković underlines the fact that there is ,almost total ethnic marginality in all spheres of socio-economic and cultural life" of the Roma population. V. Stanković, „Roma in Light of Yugoslav Statistics“, in Development of Roma in Yugoslavia - Problems and Tendencies, SANU, Belgrade, 1992, 164. Cited in B. Jakšić (2005b), 222; The former Serbian Ministry for Capital Investments also recognized that ,many Roma settlements are the most miserable parts of our cities. Although they are not the only informal settlements, although they are by size smaller than other informal settlements, they are because of poverty and discrimination in the worst position, and living is the hardest in them". Guidelines for the Improvement and Legalization of Informal Roma Settlements, 2.

45 Ibid., 13; In his famous commencement address at Howard University on June 4th 1965, former US President Lyndon B. Johnson said: „You do not take a person who, for years, has been hobbled by chains and liberate him, bring him up to the starting line of a race and then say, 'you are free to compete with all the others,' and still justly believe that you have been completely fair". See the whole speech at: http://www.lbjlib.utexas. edu/johnson/archives.hom/speeches.hom/650604.asp, last visited 11 November 2015; One illustrative fact is that $14.7 \%$ of total population of Serbia is faced with the problem of inadequate housing, while this percentage amounts to $64.1 \%$ in the Romani population. O. Balić et al., 76.

46 Different terms are used to indicate these measures, such as affirmative action, special measures, positive discrimination, positive measures, preferential system, and similar. See: Ljubica Djordjević, „Afirmativne mere za unapređenje položaja Roma u Srbiji (Affirmative Action for the Advancement of Roma in Serbia)", Prilozi Strategiji unapredjenja položaja Roma (ur. T. Varadi, D. Djordjević, G. Bašić), Zaštitnik građana, Beograd 2014, 29, 37.

47 Nuria Elena Ramos Martín, Positive Action Measures in European Union Equality Law, http://www.uva-aias.net/uploaded_files/publications/NuriaRamosMartin.pdf, last visited 10 November 2015. 
than formal equality. ${ }^{48}$ The central issue is whether the different treatment provided by an affirmative measure is justified or represents an act of discrimination. In addressing this issue, international courts mainly rely on given proportionality tests. This implies that an affirmative measure is permitted only if it is suitable and proportionate for the realization of a legitimate goal (i.e., there is no other measure which could achieve the objective while interfering less in the principle of equality). ${ }^{49}$ The draft law on the Legalization of Informal Roma Settlements proposed takes into account these criteria. Furthermore, it is based on the provisions of the Constitution of the Republic of Serbia on affirmative action. ${ }^{50}$

However, positive measures envisaged by the Constitution are not being elaborated on and implemented sufficiently by laws or bylaws in Serbia. ${ }^{51}$ The Government of the Republic of Serbia has also recognized the specific problems in legalization of Roma settlements, such as resolving the legal status of property, structure quality, building documentation,

48 Lj. Djordjević, 33; More on affirmative action, see: Milan Paunović, Boris Krivokapić, Ivana Krstić, Međunarodna ljudska prava, Pravni fakultet Univerziteta u Beogradu, Beograd 2014, 253-255.

49 Lj. Djordjević, 37; The European Court of Human Rights has confirmed in many cases that affirmative measures are permitted under Article 14 of the ECHR, which prohibits any form of discrimination. In Stec and others v. The United Kingdom, the Court underlined the following: „Article 14 does not prohibit a member State from treating groups differently in order to correct 'factual inequalities' between them; indeed in certain circumstances a failure to attempt to correct inequality through different treatment may in itself give rise to a breach of the Article (...). A difference of treatment is, however, discriminatory if it has no objective and reasonable justification; in other words, if it does not pursue a legitimate aim or if there is not a reasonable relationship of proportionality between the means employed and the aim sought to be realized". Case of Stec and others v. The United Kingdom, App. Nos. 65731/01 and 65900/01, judgment from 12 April 2006: http://hudoc.echr.coe.int/eng? $i=001-73198$, last visited 10 November 2015.

50 As a general rule, Article 21, paragraph 4. of the Constitution of the Republic of Serbia stipulates that ,special measures which the Republic of Serbia may introduce to achieve full equality of individuals or group of individuals in a substantially unequal position compared to other citizens shall not be deemed discrimination". In a more concrete way, Article 76, paragraph 3. of the Constitution of the Republic of Serbia stipulates that ,specific regulations and provisional measures which the Republic of Serbia may introduce in economic, social, cultural and political life for the purpose of achieving full equality among members of a national minority and citizens who belong to the majority, shall not be considered discrimination if they are aimed at eliminating extremely unfavorable living conditions which particularly affect them". See the complete text of the Constitution of the Republic of Serbia: http://www.wipo.int/wipolex/en/text. jsp?file_id $=191259$, last visited 10 November 2015.

${ }_{51}$ Izveštaj o sprovođenju Strategije za unapređenje položaja Roma sa preporukama, 2, 79; In a Report from 2014, it was noted that ,the current legal framework on legalization and urban planning does not recognize the specific conditions of legalization of Roma settlements/individual buildings in Roma settlements. Changes in the legal framework which would recognize these specific circumstances and enable the legal regulation of these settlements and create a foundation for further improvement of living conditions are necessary, possibly through the Lex Specialis mode“. O. Balić et al., 26. 
adequate supporting infrastructure, and other similar issues. ${ }^{52}$ In this regard, the adoption of the proposed Draft Law would represent a further step in the mitigation of the inherited problems that the Roma population has been facing for many decades.

\section{MAIN SOLUTIONS ENVISAGED BY THE DRAFT LAW ON THE LEGALIZATION OF SUSTAINABLE ROMA SETTLEMENTS}

The Draft Law on the Legalization of Sustainable Roma Settlements (hereinafter: The Draft Law) regulates the conditions, procedure and manner of legalization of sustainable informal Roma settlements, as the first stage in the process of legalization and improvement of the housing conditions of Roma in Serbia. ${ }^{53}$ Therefore, it should create prerequisites so that the residents of such settlements would, at a later stage, be able to access the legitimation of individual structures. ${ }^{54}$

A sustainable informal Roma settlement is defined as a settlement or part of a settlement predominantly inhabited by Roma, with more than 100 inhabitants of Romani ethnicity, constructed or reconstructed before 1971, from material that provides durability and safety of the structure..$^{55}$ Thus, the Draft Law focuses on larger settlements, with a longer tradition and history, which their resilience and persistence has confirmed.

52 Strategy for Improvement of the Status of Roma in the Republic of Serbia, 18.

53 Art. 1 of the Draft Law.

54 M. Davinić, V. Macura, M. Ferenček, Ž. Klisarević, O. Balić, The Draft Law on the Legalization of Sustainable Roma Settlements, Standing Conference of the Roma Associations of the Citizens - The League of Roma, Belgrade 2014, 13.

55 Art. 2 of the Draft Law; There are different definitions of informal settlements. According to OSCE report, ,, an informal settlement is any human settlement where housing has been constructed without the requisite permits or legal title for use of the land". Report on Roma Informal Settlements in Bosnia and Herzegovina, OSCE Mission to Bosnia and Herzegovina, 3: http://www.oscebih.org/documents/osce_bih_doc_2010122310144973eng. pdf, last visited 2 November 2015; The Vienna Declaration on Informal Settlements in South Eastern Europe defines them as the following: „Informal settlements are human settlements, which for a variety of reasons do not meet requirements for legal recognition (and have been constructed without respecting formal procedures of legal ownership, transfer of ownership, as well as construction and urban planning regulations), exist in their respective countries and hamper economic development. While there is significant regional diversity in terms of their manifestation, these settlements are mainly characterized by informal or insecure land tenure, inadequate access to basic services, both social and physical infrastructure and housing finance." The Vienna Declaration on Informal Settlements in South Eastern Europe: http://library.tee.gr/digital/m2267/m2267_demeti. pdf, last visited 7 November 2015; The term „Roma Settlement“ refers to any area of an urban zone that is majority populated by Roma. Synonyms for this term are „Roma mahala" and „Roma neighborhood“. Guidelines for the Improvement and Legalization of Informal Roma Settlements, 4. 
The definition of a sustainable informal Roma settlement also suggests that the objective of the Draft Law is not the legalization of all Roma settlements, but only those that meet the requirements of sustainability. Therefore, it is necessary to clearly define those situations in which the legalization of settlements would be harmful for the residents of the Roma settlement and society as a whole. ${ }^{56}$

A Roma settlement is not considered sustainable when it is predominantly constructed or reconstructed on land unfavorable for construction (landslides, permanently contaminated land, wetlands, etc.); predominantly constructed or reconstructed on land that is on someone else's private property; constructed in an area that has been assigned the first level of natural heritage protection, or in an area of protected cultural heritage of great importance; constructed in protective zones in the proximity of military facilities, and constructed in protective zones of other important structures/facilities (airports, highways, water sources, dams, etc.) that are protected in accordance with the provisions of special laws. ${ }^{57}$

It is necessary to stress that the legalization of sustainable Roma settlements does not automatically mean the legalization of any of its individual structures (houses, constructions, streets, infrastructure, etc.), but is a prerequisite for their individual legitimation in accordance with the recently adopted Law on Legitimation of Objects. ${ }^{58}$

There are different phases in the process of the legalization of informal Roma settlements, all of which establish local communities as the main actor. ${ }^{59}$ Thus, The Local Self-government unit in which Roma settlements exist is required to analyze the situation, ${ }^{60}$ determine a list of sustainable Roma settlements within its territory, ${ }^{61}$ adopt an action plan for the implementation of legalization in terms of improving the quality

56 M. Davinić et al., 14.

57 Art. 2 of the Draft Law.

58 Art. 3 (2) of the Draft Law.

59 It has been noted that the issue of legalization and improvement of Roma housing is the concern of the local community and falls within its jurisdiction. The local community and its population, of not just Roma but of all residents, are therefore those who should be key in its resolution. Guidelines for the Improvement and Legalization of Informal Roma Settlements, 13-14.

60 A situational analysis of Roma settlements specifically lists existing Roma settlements that have a population of more than 100 inhabitants of Romani ethnicity and includes information on the location, size, number of facilities, population, households, age and building quality, the extent of the area that can meet criteria for legalization of sustainable Roma settlements, a general description of the overall situation, quality review and problems within the settlement, as well as other information relevant to the decision as regards legalization accession. Art. 6 (2) of the Draft Law.

61 Local governments shall establish a list of sustainable Roma settlements within their territorial jurisdiction, based on the definition of a sustainable Roma settlement, the analysis of the situation, and the outline list of settlements given in the Appendix of the Draft Law. Art. 7 (1) of the Draft Law. 
of life, ${ }^{62}$ make a decision on the accession to the legalization of sustainable Roma settlements, ${ }^{63}$ and to develop urban plans that contain detailed regulation, including subdivision plans. ${ }^{64}$

The development of detailed urban plans is a key moment in the process of legalization. These plans do not exist for a large number of informal Roma settlements and, without them, it is not possible to legalize individual facilities nor to develop communal infrastructure within them. ${ }^{65}$ Therefore, "the legalization of a settlement by means of an urban plan is a political process, unlike the legalization of individual houses, which is an administrative process."

The local self-government unit should be responsible for the review of all applicable urban planning (mainly of a general nature) and to make amendments to individual plan sections that provide insufficient argumentation for the resettlement of Roma settlements in order to ensure that these settlements are maintained and improved in accordance with respect to the local Roma community. ${ }^{67}$ As the authors of the draft law have pointed out, urban planning has long been characterized by a

62 The action plan primarily contains the overview and content of activities to be undertaken, documents to be adopted, timelines and responsibilities for each activity, the anticipated scope and sources of funds for the realization of tasks, as well as other necessary requirements and instructions for conducting the legalization of sustainable Roma settlements. Art. 8 (2) of the Draft Law.

63 Local self-governments are to make their own respective decisions on accessing the legalization of sustainable Roma settlements on the basis of situation analysis, the established list of sustainable Roma settlements, and on the basis of the action plan for the implementation of legalization. Art. 9 (1) of the Draft Law.

64 Art. 4 of the Draft Law.

65 See: Vladimir Macura, ,Nužnost legalizacije neformalnih Romskih naselja (The Necessity of Legalization of Informal Roma Settlements)“, Prilozi Strategiji unapredjenja položaja Roma (ur. T. Varadi, D. Djordjević, G. Bašić), Zaštitnik građana, Beograd 2014, 69; In a survey conducted by the League of Roma, only one out of the 20 surveyed municipalities applied for and received funds from the state budget for the drafting of the planning documentation for irregular settlements. See: O. Balić et al., 74.

66 V. Macura, Z. Vuksanović, 8, 15.

67 Art. 10 of the Draft Law; Settlement upgrades and improvements essentially can be defined as any contributing development to a structure that improves its inhabitability. These include access to water, sanitation, electricity, roads, or any other infrastructure, as well as improvements to the building itself. Best Practices for Roma Integration, 9; ,...The issue is often raised of whether it is necessary to first perform legalization of a settlement, and then its improvement, or if the improvement is the basis for legalization. Actually, these two processes are intertwined and they support each other. Legalization supports improvement, and an improved environment provides arguments for the legalization of structures and settlements. In other words, the legalization has limited effects if it is not linked to improvement, and improvement cannot be completely advanced if it is not connected to the process of legalization". Guidelines for the Improvement and Legalization of Informal Roma Settlements, 9; However, a survey conducted by the League of Roma showed that municipalities in Serbia are not well prepared nor motivated to participate in programs aimed at improving housing conditions in Roma settlements. See: O. Balić et al., 74. 
negative attitude towards existing Roma settlements due to the matter of their informal and unincorporated appearance. Objections also include their having been built on unregulated land that is not within proper legal possession and lacks proper infrastructure. Such a disregard in urban planning for already existent Roma settlements has resulted in the total neglect of providing for their existence, and opt for the establishment of any other purposed area possible (protective zones, protective vegetation, sport and recreation, new corridors, infrastructure, and so on).$^{68}$ It is therefore obvious that this practice should be abandoned by the adoption of this Draft Law.

In the process of legalization of sustainable Roma settlements, the forced eviction of residents from the settlement is not allowed without previously having provided alternative accommodation of a quality equal or higher to the living conditions of that settlement, which must also comply with the criteria of adequate housing. ${ }^{69}$ This provision is of great importance since some facilities within a sustainable settlement would have to be removed (e.g., from safety concerns) and it is necessary to ensure their inhabitants have adequate housing. ${ }^{70}$

The lands where sustainable Roma settlements are located and which are public property should be ceded or leased to applicants in accordance with the appropriate normative acts. ${ }^{71}$ In fact, most Roma settlements are located on public lands, and, for that very reason, require conversion from public to private ownership, or, at the very least, the opportunity of long-term land lease. Furthermore, the cession or lease of land should not be done under bidding procedure, due to the poor material situation of their inhabitants and the clear danger of the land being taken over by much wealthier tender participants. ${ }^{72}$

Local self-governments and civil society organizations shall carry out the planning and improvement of settlements, as well as other programs necessary for their overall development. ${ }^{73}$ On the state level, the

68 See: M. Davinić et al., 16.

69 Art. 12 of the Draft Law; The Ministry of Construction, Transport and Infrastructure opened the public debate on the draft Law on housing and building maintenance in November, 2015. This draft Law regulates, among other things, the processes of forced evictions and displacements, as well as housing support for the socially vulnerable inhabitants, which is an overt positive step. However, this law cannot be a substitute, but rather a necessary supplement for the Law on Legalization of Sustainable Informal Roma Settlements. About the need for the enactment of a special law that would regulate a process of forced evictions and displacements in detail, see: Marko Davinić, „Prinudno iseljenje i raseljavanje - upravno-pravni aspekti (Forced evictions and displacements - Administrative Law Aspects)“, Anali Pravnog fakulteta u Beogradu 2/2013, 149-165.

70 M. Davinić et al., 17.

71 Art. 14 of the Draft Law.

72 M. Davinić et al., 17.

73 Art. 16 (1) of the Draft Law. 
Ministry assigned the duty of legalization must be required to establish an internal organizational unit which shall be held responsible for activities related to the legalization of sustainable Roma settlements. ${ }^{74}$

The draft Law foresees adoption of bylaws necessary for its implementation. Thus, the Government of the Republic of Serbia is to adopt a regulation which prescribes the manner and conditions of the cession or lease of land in the legalization of sustainable Roma settlements. Furthermore, the Minister in charge of construction shall establish a rulebook of subdivision and regulation of sustainable Roma settlements. ${ }^{75}$ Such a rulebook is necessary for the sake of traditional specifics of construction and demarcation of structures in Roma settlements. These rules are not to be in collision with the standards of safety, health and hygiene, but refer to the recommended road profiles (for example, roads in Roma settlements are approximately 3-4 meters wide, instead of the typical residential street with a 6 meter span and $2 \times 1.5$ meters of pedestrian sidewalk). ${ }^{76}$ Lowering technical standards of construction have proved to be of crucial importance, though this tolerance must not come at the expense of the safety and security of the inhabitants. ${ }^{77}$

Finally, the Draft Law does contain the standard sections on penalties and supervision, as well as transitional and final provisions. ${ }^{78}$

\section{CONCLUSION}

Together with education, healthcare and employment, housing represents the main area needed for comprehensive development of Roma society in the Republic of Serbia. Although in the first three areas discernible progress has been achieved over the last few years, housing has still remained on the fringe.

The proposed draft Law on the Legalization of Sustainable Informal Roma Settlements should serve as a precondition and create prerequisites in order that the residents of such settlements would, at a later stage, be able to access the legitimation of individual structures according to the recently adopted Law on the Legitimation of Buildings. Nevertheless, the latter has caused much heated controversy in public debate owing to the reasonable question as to whether the process of legitimation undermines the principle of equality and non-discrimination due to privi-

\footnotetext{
74 Art. 17 of the Draft Law.

75 Art. 18 of the Draft Law.

76 M. Davinić et al., 18.

77 See: Đ. Mojović, M. Ferenček, 131.

78 Art. 19-23 of the Draft Law.
} 
leges that illegal builders will enjoy. After all, this was the main reason for the adoption of the Constitutional Court's decision in 2012 on the unconstitutionality of the provisions stipulated in the Law on Planning and Construction of 2009.

Even if the new Law on the Legitimation of Buildings passes the test of its constitutionality, it still will not enable the majority of residents of informal Roma settlements to legitimize their individual buildings due to the unfortunate substandard nature of these settlements (most of which are built on land in public ownership or is of an unregulated or unclear legal status). Furthermore, the settlements themselves in how they have been laid out are often in stark contrast from the standards of the majority of the population (e.g., street width) which further hinder legitimization of the facilities located within. Does the inability of the legitimation of these structures and the nonexistence of detailed urban plans for such settlements automatically imply their removal at a later stage? This outcome would probably not prove to be the case due to the inability of the state to provide feasible solutions to their inhabitants. Sadly, this would also mean that the inhabitants of these settlements will continue to live in a legal limbo, under the constant fear of forced evictions and displacements.

The proposed draft Law together with appropriate bylaws would resolve the preliminary issue of the legal status of the land on which a settlement is located, as well as enable the development of its inhabitability in terms of structure quality and supporting infrastructure.

It goes without saying, that the legalization of informal Roma settlements would not cover all such settlements that have been registered in the Republic of Serbia. Regardless of the typology that is taken into account, slums are categorically unable to be improved nor legalized as being hazardous for their inhabitants. They will eventually need to be removed and feasible alternatives provided. Furthermore, only those settlements that meet the requirements of sustainability are to be considered to be involved in the process of legalization.

Naturally, the legalization of settlements would represent only the first step and a basis for further improvement to the conditions in which the Roma live. The entire process, despite the best of expectations, is surely to last for several generations. However, this would only be a second compared to the centuries in which this population has been living in inhuman conditions.

\section{REFERENCES}

Balić O., Ergić Đ., Nikolić S., Jovanović Đ., Vasić S., Civil Society Monitoring on the Implementation of the National Roma Integration 
Strategy and Decade Action Plan in Serbia in 2012 and 2013, Decade of Roma Inclusion Secretariat Foundation, Budapest 2014.

Bašić G., „Settlements and Population Density of the Romanies in Serbia“, Umetnost preživljavanja, Gde i kako žive Romi u Srbiji (ur. B. Jakšić, G. Bašić), Institut za filozofiju i društvenu teoriju, Beograd 2005.

Bašić G., „Siromaštvo Roma i afirmativne mere (Roma Poverty and Affirmative Action)“, Prilozi Strategiji unapredjenja položaja Roma (ur. T. Varadi, D. Djordjević, G. Bašić), Zaštitnik građana, Beograd, 2014.

Belić M., „Legalizacija bespravno sagrađenih objekata“, Bilten republičkog javnog pravobranilaštva 1/2014.

Davinić M., „Prinudno iseljenje i raseljavanje - upravno-pravni aspekti (Forced evictions and displacements - Administrative Law Aspects)“", Anali Pravnog fakulteta u Beogradu 2/2013.

Davinić M., Macura V., Ferenček M., Klisarević Ž., Balić O., The Draft Law on the Legalization of Sustainable Roma Settlements, Standing Conference of the Roma Associations of the Citizens - The League of Roma, Belgrade 2014.

Djordjević Lj., „Afirmativne mere za unapređenje položaja Roma u Srbiji (Affirmative Action for the Advancement of Roma in Serbia)", Prilozi Strategiji unapredjenja položaja Roma (ur. T. Varadi, D. Djordjević, G. Bašić), Zaštitnik građana, Beograd 2014.

Ethnic Minorities in Serbia, An Overview, OSCE, February 2008, 19: http://www.osce.org/serbia/30908?download=true, last visited 20 October 2015.

http://www.politika.rs/rubrike/Ekonomija/Legalizacija-sesti-put-za-desetgodina.lt.html, last visited 30 September 2015.

http://www.politika.rs/rubrike/Ekonomija/Pocinje-legalizacija-po-novimpravilima.lt.html, last visited 25 October 2015;

Izveštaj o sprovođenju Strategije za unapređenje položaja Roma sa preporukama, Zaštitnik građana, Beograd 2013, 1, 105-106: http:// www.ombudsman.rs/attachments/3115_IZVESTAJ\%20ZG\%20 O\%20SPROVODJENJU\%20STRATEGIJE.pdf, last visited 1 November 2015.

Jakšić B., „Living conditions of the Roma family in Serbia“, Umetnost preživljavanja, Gde i kako žive Romi u Srbiji (ur. B. Jakšić, G. Bašić), Institut za filozofiju i društvenu teoriju, Beograd 2005.

Jakšić B., „Uslovi života romske porodice u Srbiji“, Umetnost preživljavanja, Gde i kako žive Romi u Srbiji (ur. B. Jakšić, G. Bašić), Institut za filozofiju i društvenu teoriju, Beograd 2005. 
Kostić I., „Romi u Srbiji - glavni problemi i prepreke u pristupu pravima (The Roma in Serbia - The Main Problems and Obstacles in Accessing Rights)“, Prilozi Strategiji unapredjenja položaja Roma (ur. T. Varadi, D. Djordjević, G. Bašić), Zaštitnik građana, Beograd 2014.

Lyndon B. Johnson's speech at Howard University on June 4th 1965, former US President Lyndon B. Johnson http://www.lbjlib.utexas. edu/johnson/archives.hom/speeches.hom/650604.asp, last visited 11 November 2015.

Macura V., „Nužnost legalizacije neformalnih Romskih naselja (The Necessity of Legalization of Informal Roma Settlements)“, Prilozi Strategiji unapredjenja položaja Roma (ur. T. Varadi, D. Djordjević, G. Bašić), Zaštitnik građana, Beograd 2014.

Macura V., Vuksanović Z., Roma Housing and Settlements in South-East Europe, Profile and Achievements in Serbia in a Comparative Framework, Summary and Recommendations, OSCE, ODIHR, Warsaw 2006.

Mojović Đ., Ferenček M., Izazovi regularizacije neformalnih naselja u jugoistočnoj Evropi, Pregled relevantnih zakona i prakse iz oblasti urbanističkog planiranja i legalizacije, NALAS (Network of Associations of Local Authorities of South-East Europe), Skoplje, 2011.

Paunović M., Krivokapić B., Krstić I., Međunarodna ljudska prava, Pravni fakultet Univerziteta u Beogradu, Beograd 2014.

Petrušić N., „Tipologija slučajeva diskriminacije Roma u pravnoj praksi Poverenika za zaštitu ravnopravnosti (Classification of cases of Discrimination Against Roma in the Legal Practice of Comissioner for Protection of Equality)“, Prilozi Strategiji unapredjenja položaja Roma (ur. T. Varadi, D. Djordjević, G. Bašić), Zaštitnik građana, Beograd 2014.

Ramos Martín N. E., Positive Action Measures in European Union Equality Law, http://www.uva-aias.net/uploaded_files/publications/ NuriaRamosMartin.pdf, last visited 10 November 2015.

Report on Roma Informal Settlements in Bosnia and Herzegovina, OSCE Mission to Bosnia and Herzegovina, 3: http://www.oscebih.org/ documents/osce_bih_doc_2010122310144973eng.pdf, last visited 2 November $20 \overline{1} 5$.

Self-made Cities, In Search of Sustainable Solutions for Informal Settlements in the United Nations Economic Commission for Europe Region, United Nations, New York - Geneva 2009.

Stanković V., „Roma in Light of Yugoslav Statistics“, in Development of Roma in Yugoslavia - Problems and Tendencies, SANU, Belgrade, 1992.

Vuksanović-Macura Z., ,The Mapping and Enumeration of Informal Roma settlements in Serbia“, Environment \& Urbanization 2/2012. 
Др Марко Давинић

ванредни професор

Правни факултет Универзитета у Београду

\author{
ЛЕГАЛИЗАЦИЈА НЕФОРМАЛНИХ \\ РОМСКИХ НАСЕЉА У РЕПУБЛИЦИ СРБИЈИ \\ - НЕОПХОДАН КОРАК ПРЕ ОЗАКОЮЕЬА -
}

\title{
Резиме
}

Аутор се у раду бави питањем могућности легализације неформалних ромских насеља у Републици Србији. Преднацрт Закона о легализацији одрживих неформалних ромских насеља, који је израдила група експерата 2014. године, требало би да створи претпоставке за озакоњење појединачних објеката у оваквим насељима у складу са недавно усвојеним Законом о озакоњењу објеката. Аутор у раду заступа став да новоусвјени закон не омогућава становницима неформалних ромских насеља да озаконе своје објекте због специфичне природе оваквих насеља (већина њих је изградјена на земљишту које је у јавној својини, или земљишту чија власничка структура није јасна и одређена). Такође, многа од ових насеља су изградјена у супротности са уобичајеним стандардима изградње (нпр. у вези са ширином улица), што ће додатно да отежа процес озакоњења појединачних објеката у њима. Усвајање Закона о легализацији одрживих неформалних ромских насеља, заједно са одговарајућим подзаконским прописима, решило би претходно питање правног статуса земљишта на коме се налазе оваква насеља, а такодје би допринело њиховом уређењу у погледу квалитета изградјених објеката и развоја додатне инфраструктуре. Аутор закључује да се легализација неформалних ромских насеља не би односила на сва ромска насеља која се налазе у Републици Србији, већ само она која испуњавању критеријуме одрживости. Наравно, легализација одрживих ромских насеља представљала би само први корак и предуслов за даље унапређење услова у којима Роми живе.

Кључне речи: Неформална ромска насеља. - Легализачија. - Озакоњење. - Одрживост. - Посебне мере.

Article history Received: 29. 10. 2015. Accepted: 18. 12. 2015. 